\title{
NEW RAW MATERIALS FROM THE NEW WORLD: TRANSFER OF KNOWLEDGE TO POLISH PHARMACIES
}

\begin{abstract}
Cataloguing of the natural world was started by the $16^{\text {th }}$-century scholar Ulisses Aldrovandi, who was inspired by overseas expeditions. Collectors of specimens, among whom were many doctors of medicine and pharmacists, noticed the possibilities for using exotic plants and animals in medicine. The first pharmacopoeias, however, contained very few of the previously unknown raw materials and they did not have a great impact on the contemporary therapeutic possibilities. In the Polish territories, the raw materials from the New World had already been recorded in Jan Woyna's Krakow Pharmacopoeia of 1683, in which five American species were identified. By contrast, in the $18^{\text {th }}$-century Jesuit pharmacies, 30 such materials were already used, although they were not pharmacopoeial.

In the $18^{\text {th }}$ century, in the Polish lands, an important role was played by duchess Anna Jabłonowska (17281800), who gathered one of the richest natural history collections in Europe in Siemiatycze in Podlasie. Thanks to her support, the Polish nature literature was enriched with numerous works that were of importance for the development of the natural sciences.
\end{abstract}

Keywords: cabinets of natural history, exotic plants, exotic raw materials, Podlasie, Anna Jabłonowska.

\section{Geographical discoveries and progress in natural sciences}

The main reason for the slow development of the natural sciences until the Renaissance was primarily the underestimation of the importance of observa-

- Address for correspondence: Instytut Historii Nauki PAN im. Ludwika i Aleksandra Birkenmajerów, ul. Nowy Swiat 72,00-330 Warsaw, Poland. Email: iarabas@wp.pl. 
tion in the natural environment. There had been some attempts made to develop the so-called summum genus - a collection of classified specimens, but science was still based on the Aristotelian tradition. The rereading of the ancient works of Pliny, Theophrastus and Dioscorides in their original versions provoked travels to the Middle East to study the plant species they had described. An additional impulse to accumulate and systematize the knowledge of the surrounding world was provided by the great geographical discoveries of the late $15^{\text {th }}$ and first half of the $16^{\text {th }}$ century.

The naturalists were greatly inspired by the text of The Diaries of Christopher Columbus ${ }^{1}$, first published in 1550 . Under the date of October 21, the following description can be found, which could have made an impact on the working of their imagination:
Sunday, $21^{\text {st }}$ of October
[...] I would not allow anything to be touched but set out with the captains and people to explore the island. If the others already seen are very beautiful, green, and fertile, this is much more so, with large trees and very green. Here there are large lagoona with wonder- ful vegetation on their banks. Throughout the island all green, and the herbage like April in Andalusia. The song of the birds was so pleasant that it seemed as if a man could never wish to leave the place. The flocks of parrots concealed the sun; and the birds were so numerous, and of so many different kinds, that it was wonderful. There are trees of a thousand sorts, and all have their several fruits; and I feel the most unhappy man in the world not to know them, for I am well assured that they are all valuable. I brought home specimens of them, and also of the land. ${ }^{2}$

The information about the existence of nature unknown to contemporary science undermined the completeness of the works of ancient authors and their stored knowledge from ancient times needed to be supplemented. The Latin version of the work of Dioscorides by Pietro Andrea Matthioli (1501-1578) ${ }^{3}$ had become the bridge between the knowledge available in ancient and modern science. Matthioli made an attempt to identify the plants mentioned by Dioscorides and supplemented the work with species unknown by the Greek physician (their number doubled from 600 to 1200). It had been the first attempt to inventory the flora of Central Europe ${ }^{4}$.

In the works of Matthioli and his contemporaries Leonhart Fuchs (15011566) and Conrad Gesner (1516-1565) there also appeared, albeit to a small

\footnotetext{
${ }^{1}$ See Z. Waźbiński, Ut Ars Natura ... , pp. 5-9 \& A. Ubrizsy-Savoia, The influence of new species ... .

${ }^{2}$ American Journeys Collection, Journey of the First Voyage of Columbus, document no. aj-062. Wisconsin Historical Society 2003, p. 125.

${ }^{3}$ See P. A. Matthioli, Commentarii ... .

${ }^{4}$ See Z. Waźbiński, Ut Ars Natura ..., p. 140.
} 
extent, some American plants ${ }^{1}$. This was mainly due to a problem with their classification. Species not described by the ancients raised doubts as to their existence. Specimens imported from the New World, never before seen or described, undermined the authority of ancient authors and the current system of studying nature. So, there were some attempts made to attribute the American species to an African origin. In turn, plants from a zone similar to that of southern Spain (although of different taxa than those found in the Mediterranean basin), raised the question of whether they had been unknown, or only so far undescribed ${ }^{2}$.

The fascination with new possibilities of penetrating the unknown nature overwhelmed many naturalists for whom the use of knowledge acquired in a second-hand manner, and not in the field work, was insufficient ${ }^{3}$. One of them was Ulysses Aldrovandi (1522-1605), who even planned an expedition to the New Continent. At that time, he saw a great need for a methodical description and classification of the plants and animals of which he had learnt by collecting illustrations, specimens and information connected to American nature. $\mathrm{He}$ wanted to verify the scientific value of the knowledge provided by the authors such as Francisco López de Gómara (1510-1566) and Gonzalo Fernandes Oviedo y Valdes $(1478-1557)^{4}$.

He did not succeed in this venture, but he realized his dream of getting to know and describe nature by conducting research on the vegetation of the Apennine Peninsula available to him. By describing and classifying all the plants known to him, he began a general inventory of the world ${ }^{5}$. He was also a precursor of those creating nature collections. His Bologna protomuseum of natural history, which he called a theatre or microcosm of nature ${ }^{6}$, comprised about 18,000 exhibits and 7,000 dried plants. He noted many exotic plants from the botanical garden and their pictorial representations.

A fascination with exotic nature has become one of the most characteristic features of modern culture. Natural peculiarities were desirable collectors' items, which, like other collections, were described and catalogued. At that time, the number of known species began to increase rapidly: from about 1,000 in the pre-Columbian era to 6,000 in the early $17^{\text {th }}$ century. But still [b]otanical goods were imported: knowledge, by and large, was not $t^{7}$.

The new phase of nature research involved the organization of professional research institutions working on the flora of Europe and newly discovered overseas territories. The period of time when the methodological foundations of modern natural sciences were created was even defined by dates: 1483 - the

\footnotetext{
${ }^{1}$ See A. Ubrizsy-Savoia, The influence of new species ... .

${ }^{2}$ See A. Ubrizsy-Savoia, The influence of new species ....

${ }^{3}$ See D. Bleichmar, Books, Bodies, and Fields ..., , p. 84.

${ }^{4}$ See M. Cermenati, Ulisse Aldrovandi e l'America.

${ }^{5}$ See G. B. Risse, Transcending cultural barriers ... , Z. Waźbiński, Ut Ars Natura ..., , p. 9, K. Lebek, Osobliwości natury a metoda ..., P. Oszajca \& Z. Bela, Ulisses Aldrovandi ... , pp. 169-179.

${ }^{6}$ E. R. Simili, Il teatro della natura di Ulisse Aldrovandi, p. 20.

${ }^{7}$ C. Swan, Collecting Naturalia ..., p. 233.
} 
publication of the Latin translation of Theophrastus' work ${ }^{1}$, and 1623 the publication of the work of Kasper Bauhin ${ }^{2}$, compiling synonyms of all plants known at that time. In Poland, the dates of the botanical renaissance are shifted, as the beginning will be only the $16^{\text {th }}$ century and the end will fall in the first half of the next century ${ }^{3}$.

\section{Medicinal raw materials from the New World}

In the first half of the $16^{\text {th }}$ century, the interest in America's nature was reduced to strictly medical and commercial purposes ${ }^{4}$. Specimens imported from the New World enjoyed the great interest of collectors, among whom there were many representatives of medical sciences. In Europe, the common belief in the special power of rare and therefore very expensive raw materials meant that exotic plants were highly valued in the pharmaceutical market. There were also gardens at pharmacies, in which pharmacists (thinking of patients) tried to acclimatize overseas plants. Thus, doctors and pharmacists who saw the potential for using exotic raw materials in medicine were among the first to learn about the new species ${ }^{5}$.

The study of the exotic flora was facilitated by the work of Carolus Clusius (1526-1609) Exoticorum libri decem (1605) ${ }^{6}$, which is his most significant publication preceded by Latin translations of the works of Garcia da Orta from 1567, Nicolas Monardes from 1574 and Cristobal Acosta from 15827.

Hope for acquiring new, unknown herbs meant that expeditions organized at the end of the $17^{\text {th }}$ century had strictly defined goals, among which there was also the acquisition of pharmaceutical raw materials ${ }^{8}$. These materials enriched the collections of the cabinets and botanical gardens - living museums of the plant world ${ }^{9}$, often known as apothecary gardens.

An example of the growing role of these gardens can be seen in the Royal Garden of Medicinal Plants in Paris founded by Louis XIII in 1635 and transformed in 1793 into the Museum of Natural History (now Muséum National d'Histoire Naturelle) - one of the world's largest nature museums to this day. Its purpose, since its inception, has been scientific activity, documentation of discoveries and classification of specimens obtained from the natural state. One of the creators of the intellectual movement of natural philosophers English

\footnotetext{
${ }^{1}$ See Theophrastus, De historia et causis plantarum.

${ }^{2}$ See K. Bauhin, Pinax theatri botanici.

${ }^{3}$ See A. Zemanek, Renaissance botany and modern science \& A. Zemanek, Botanika Renesansu .... .

${ }^{4}$ See A. Ubrizsy-Savoia, The influence of new species ... .

${ }^{5}$ See I. Arabas, Przyrodnicy, kolekcjonerzy i teoretycy muzealnictwa.

${ }^{6}$ See S. Anagnostou, The international transfer of medicinal drugs ...

${ }^{7}$ See A. Zemanek, A. Ubrizsy-Savoia \& B. Zemanek The beginnings of ecological thought in the Renaissance ..., C. Swan, Collecting Naturalia ... , p. 234 \& J. De Koning, G. Van Uffelen, A. Zemanek \& B. Zemanek, Drawn after nature ..., p. 368.

${ }^{8}$ The utilitarian approach to studying the world of plants resulted in, for instance, the Siberian expeditions organised by the Medical Office during the reign of Peter the Great (1672-1725).

${ }^{9}$ See A. Zemanek, Renaissance botany and modern science.
} 
naturalist John Ray (1627-1705), said that it is an age of daily progress in all the science, especially in the history of plants ${ }^{1}$.

Medicinal preparations from Latin America became more and more known, and the confirmation of this fact is their presence in the $18^{\text {th }}$ century not only in the pharmacies of European cities, but also in such exotic places as Luanda, Canton and Morocco $^{2}$.

In Poland, news about the New World, and in particular its nature, appeared sporadically in the literature ${ }^{3}$. The first information about American plants already appeared in the Renaissance herbaria, but their number was negligible. It could have been caused by the limited availability of exotic species in our lands, and these works were intended for a wide audience. However, what was significant was the statement of Marcin of Urzędow from the end of the $16^{\text {th }}$ century, who mentioned in the introduction to the herbarium Herbarz Polski that the physicians turned to overseas and foreign drugs $[\ldots]^{4}$.

\section{Collections as a research workshop}

Rich collector-naturalists gave support to expeditions paying high prices for imported plants and animals, financed the work of scholars, and made their collections available to those interested. Contemporary historians often see in this movement an attempt to include natural history in the sphere of possession, because the owners of valuable collections became, in a sense, holders of the knowledge which could be obtained through the use of specimens. On the other hand, for the Franciscan monk Yves de Paris (1588-1678) $)^{5}$ knowledge replaced possession, which he considered useless, although it led to real intellectual - possession ${ }^{6}$. Natural history collections could therefore be a source of knowledge and encouragement for research: knowing is possessing.

During the Enlightenment, collections took on the character of a research workshop as opposed to a library approach. Collecting and utilitarianism caused a broad discussion about exotic plants and their importance in pharmacy. One of the participants was Jean-Jacques Rousseau (1712-1778) ${ }^{7}$, who included his original observations on acclimatization of exotic plants in his unfinished Botanical Dictionary, where he wrote: Plants which have been transported away from their native climate undergo far-reaching changes. Those that are perennial in warm countries become annual in our country - and this is not the only change that happens to them in our gardens. ${ }^{8}$ However, he opposed to the

\footnotetext{
${ }^{1}$ Ch. E. Raven, John Ray ..., p. 251.

${ }^{2}$ See S. Ganger, World Trade in Medicinal Plants ....

${ }^{3}$ See A. Elbanowski, Nowy Świat w polskich dykcjonarzach ... \& A. Elbanowski, Obraz Nowego Świata ... .

${ }^{4}$ Marcin z Urzędowa, Herbarz Polski, To the reader.

${ }^{5}$ See R. P. Ch. Chesneau, Thèse ... .

${ }^{6}$ See Yves de Paris, La théologie naturelle, pp. 31-32.

${ }^{7}$ See J. J. Rousseau, The Reveries of the Solitary Walker, pp. 92-94 \& J. Czerzeniewska, Zbieractwo jako krytyka kultury.

${ }^{8}$ E. Sadurska-Duffy, Botanika jako źródło naukowej i osobistej refleksji, p. 265.
} 
very popular image of botany as a field of medical science. With indignation he quoted the story of a Frenchman from Paris, who seeing in London a connoisseur's garden full of rare trees and plants, cried out as his sole praise: "That is a very fine apothecary's garden". ${ }^{1}$

At the time in the cabinets of natural history first of all innumerable objects of the same kind or type, to study the evolution of forms and to explain it to visitors in a visual way ${ }^{2}$ were collected. The Encyclopaedists movement ${ }^{3}$ and the Encyclopedia ${ }^{4}$ flagship work were not without significance for the creation of specialized collections and the awareness of the need to classify them. One of the authors of the Encyclopedia, Denis Diderot, emphasized the importance of the study of nature, which produces a taste for natural history. There was a fashion for science among the elite of the enlightenment of Europe, and studying plants and animals became an obsession of the connoisseurs.

\section{Cabinets of natural history as a place for acquiring knowledge}

Cabinets of natural history, very popular in Europe in the $18^{\text {th }}$ century, originally derived from the tradition of cabinets of curiosities ${ }^{5}$, became an important destination points during the Western European journeys of the aristocrats. This was also the case among the Polish elites. One of the obligatory places to visit was Paris. On the way there from the Polish lands, the cabinets of, among others, King August II the Strong in Dresden, Jean Hermann in Strasbourg and numerous ones in the French provinces (there were several thousand of them) were eagerly visited ${ }^{6}$.

It is thanks to the accumulated knowledge and purchases made during such trips that Duchess Anna Paulina Jabłonowska née Sapieha, palatine of Bracław $(1728-1800)^{7}$, created one of the richest Cabinets of Natural History in Europe ${ }^{8}$. After she got married to Jan Kajetan Jabłonowski (1699-1764), in the 1750s they set off on a honeymoon lasting for several years, during which she was presented at the most important European royal courts. When in 1770, after the death of her husband, she set off on her second journey to Western Europe accompanied by Captain Henryk Greybner, it was probably her goal to establish contacts with naturalists and buy valuable collections. They visited France,

\footnotetext{
${ }^{1}$ J. J. Rousseau, The Reveries of the Solitary Walker, p. 94.

${ }^{2}$ S. Lorentz, Filozofia muzeów, p. 10.

${ }^{3}$ See M. Skrzypek, Filozofia Diderota, pp. 22-52.

${ }^{4}$ The Encyclopedia (Encyclopédie, ou Dictionnaire raisonné des sciences, arts et métiers ... ), published in the years 1751-1772, was the greatest literary undertaking of the Enlightenment.
}

${ }^{5}$ See P. Findlen, Possessing Nature ..., D. Bleichmar \& P. Mancall, Collecting across Cultures ..., O. Impey \& A. MacGregor (eds.), The Origins of Museums ... \& L. Daston \& K. Park, Wonders and the Order of Nature $(1150-1750)$

${ }^{6}$ See P. Daszkiewicz, Polacy odwiedzający gabinet historii naturalnej ... .

${ }^{7}$ The eldest daughter of Karolina Teresa née Radziwiłł and her first husband, Kazimierz Leon Sapieha. After the death of her father, from whom she inherited estates in Podlachia, Lublin Voivodeship and Volhynia, she was raised by her stepfather. In 1750 she married Jan Kajetan Jabłonowski (1699-1764), her stepfather's paternal cousin.

${ }^{8}$ See P. Daszkiewicz \& A. Bauer, Specimens from the second collection of Albertus Seba ... . 
Italy, Switzerland, England, the Netherlands, and Germany. In Paris, the Muséum d'Histoire Naturelle collection was already famous at that time.

Anna Jabłonowska certainly had become fashionable, but she was also a well-prepared naturalist thanks to her stepfather, Józef Aleksander Jabłonowski (1711-1777), the creator of the Societas Jablonoviana in Leipzig. Jabłonowska's collection was much larger than one could show in her Cabinet of Natural History. Perhaps she even favoured older collection programmes and paid attention to aesthetic values and the attractiveness of the exhibits for her guests ${ }^{1}$.

The collection, which was created in the Polish province, in the estate of duchess Anna Jabłonowska in Siemiatycze in Podlasie ${ }^{2}$, was mentioned by Antoine Joseph Dezaillier d'Argenville in the third volume of his La Conchylologie:

The most complete, privately-owned cabinet located outside of Warsaw, is the one that belongs to Madame the Duchess Palatine of Bractaw. A true enthusiast of the beauties of nature, she has been gathering at great cost for many years and never ceases to augment their numbers. Shells, insects, quadrupeds, reptiles, minerals, stones, bitumen, wood, plants - nothing has been forgotten. The part containing shells is magnificent and has been assembled with utmost diligence. The same applies to the collection of wood - there can hardly be a more complete one. ${ }^{3}$

He also added a comment on the topic of the popularity of assembling collections and the development of natural sciences in Poland: The passion for exact sciences is not yet widespread enough in Poland [...]. If the land is marked with unprecedented revolutions and civil wars, unfortunate for both sides, it will be all the more marked with swift progress of sciences and arts. ${ }^{4}$

Duchess Anna Jabłonowska became the best example of it. According to the words of Remigiusz Ladowski (1738-1798), she was the first to instill the study of natural history [...] in our country $[. . .]^{5}$. It is thanks to her that Polish literature was enriched by the work of priest Krzysztof Kluk (1739-1796) ${ }^{6}$ and the quoted Piarist Remigiusz Ładowski ${ }^{7}$. These naturalists are both referred to in Polish literature in the context of a common place of acquiring knowledge, which was the Cabinet of Natural History and the library in Siemiatycze and the garden in Kock.

\footnotetext{
${ }^{1}$ See O. Topol, Deliss. Plaszczyzny percepcji, p. 402 \& K. Jagodzińska, Czas muzeów w Europie Środkowej.

${ }^{2}$ See I. Arabas, A case study of the role of $18^{\text {th }}$-century natural history cabinets ... .

${ }^{3}$ A. J. Dezallier d'Argenville, La Conchyliologie ..., vol. 2, p. 826. The second volume contains appendices Additions et corrections à faire aux deux premiers volumes de cet ouvrage which include the chapter Additions aux cabinets des pays étrangers.

${ }^{4}$ A. J. Dezallier d'Argenville, La Conchyliologie ..., , vol. 2, p. 825.

${ }^{5}$ R. Ładowski, Historia naturalna Królestwa Polskiego ..., Dedication.

${ }^{6}$ See Z. Wójcik, Ksiądz Jan Krzysztof-pisarz i uczony \& G. Brzęk, Krzysztof Kluk.

${ }^{7}$ See Z. Wójcik, Aleksander Sapieha ..., pp. 41-42.
} 


\section{Curiosity subjected to discipline}

Confronting the merits for science of these two naturalists was always unfavorable to Father R. Ladowski. The work on the natural history of the Kingdom of Poland by priest R. Ładowski was one of the last ones belonging to the baroque trend of popularizing knowledge in encyclopedic terms, known as scientia curiosa ${ }^{1}$, which at the same time closed the era of curiosity ${ }^{2}$. This type of literature had a great effect on the imagination of readers, just like the cabinets of curiosities ${ }^{3}$

In turn, Krzysztof Kluk was the author of naturalist and agricultural works appreciated by the National Education Commission - the first Ministry of Education in Europe. His work was of great importance for the development of natural sciences in Poland and for many years was the main source of botanical and pharmaceutical knowledge.

The merit of Krzysztof Kluk was the introduction, for the first time to the Polish literature, of a double nomenclature of species according to the Linnaean system. In Dykcjonarz roślinny (Encyclopedia of Plants) ${ }^{4}$ he encouraged the acclimatization of plants from the New World, which he could familiarize himself with thanks to the gardens, orangeries and herbaria of Duchess A. Jabłonowska. The images of American nature was supplemented in his work Zwierzat domowych $i$ dzikich ... ${ }^{5}$ about domestic animals and wild animals. In the chapter About the Natural Cabinet, he emphasized that it was thanks to Jabłonowska's Cabinet that he could become acquainted with unknown natural specimens. Also, there he could recognize medicinal plants, which were often confused, because they were known only from their description. He also saw the important role of the cabinets in learning about the differences between plants from different climatic zones and in the investigation of systematic order. He wrote: Cabinets are helpful in the ever more precise organization of systems $[\ldots]^{6}$.

\section{Exotic plants in Podlasie}

K. Kluk and R. Ładowski could also learn from the plants growing in the summer residence of Duchess Jabłonowska in Kock, where 590 species of shrubs and trees were planted on thirteen hectares, including North American plants from Florida, Carolina and Canada ${ }^{7}$. In her residences, Jabłonowska kept gardeners, often foreigners, who arranged gardens, orangeries and trebhauzies for her. She could thus grow exotic plants and try to acclimate them. One innovation in the field of gardening was the introduction of hotbeds: The duchess not only had orangeries, but also hothouses full of living curiosities, as well as a lot of flowers - she loved them and spared no expense on them. [...] In

\footnotetext{
${ }^{1}$ See T. Bieńkowski, Polscy przedstawiciele „scientia curiosa”.

${ }^{2}$ See K. Pomian, Zbieracze i osobliwości.

${ }^{3}$ See J. Kołodziejczyk, X. Ładowski i jego „Historia Naturalna, przez alfabet ułożona”.

${ }^{4}$ See K. Kluk, Dykcjonarz roślinny ... .

${ }^{5}$ See K. Kluk, Zwierząt domowych i dzikich ..., vol. 1-4 (1779-1780).

${ }^{6} \mathrm{~K}$. Kluk, Zwierząt domowych i dzikich ..., vol. 1, p. 22.

${ }^{7}$ See I. Arabas, $A$ case study of the role of $18^{\text {th }}$-century natural history cabinets ... .
} 
her many estates she employed well-paid gardeners, often foreigners, who arranged magnificent gardens, orangeries and Treibhäuser. ${ }^{1}$

She was also the author (translator and compiler) of numerous works from which the most important, in my opinion, is the book based on Richard Bradley's work ${ }^{2}$. The most interesting feature of this book is the presence of very meticulously prepared tables with a register of plants, probably grown in her gardens.

Two very important Polish naturalists, K. Kluk and R. Ładowski, learnt about exotic plants in gardens, orangeries and trebhauzies at the Duchess's estate in Kock and Siemiatycze. It is interesting to compare the knowledge from the works written in Podlasie with the contents of Jabłonowska's Cabinet of Natural History. Dykcyonarz by K. Kluk was an original work devoted only to plants. Plants alien to Polish flora were marked by K. Kluk in the following way: one star - the plants already known, but previously alien to Polish nature, and two stars - the unknown plants - exotic. A. Jabłonowska listed a total of 516 plants (in three tables) ${ }^{3}$, and K. Kluk confirmed the knowledge of $70 \%$ of them (349 plants) ${ }^{4}$. Among those 516 plants, 58 were described by K. Kluk as exotic to Polish lands, and 77 as alien but already common. Fifty-five of them were classified as American.

Dykcjonarz stużacy do poznania historyi naturalney by R. Ładowski was a translation of the dictionary by Charles-Antoine-Joseph Leclerc de Montlinot and, in its character, it is close to the tradition of scientia curiosa. R. Ladowski mentioned only several plants that could be found in the Duchess's gardens. I found it fascinating to search for plants from the New World in the Cabinet of Natural History of Anna Jabłonowska. Even more fascinating is the fact that the same species of plants reappeared in the works of K. Kluk and R. Ladowski.

In Jabłonowska's Cabinet of Natural History according to the list made by Count Soltyk, there were at least 51 species imported from the New World, which constituted about $50 \%$ of the listed species. The author of the list wrote about this part of the Cabinet:

This part of the Cabinet of Natural History, founded by

Duchess Anna Jablonowska, compared with other collections is less rich than its intentions. Having encountered impassable difficulties, which are often encountered when creating a herbarium or plant collections at an above-average level, not to be limited to native plants, and wanting to bring closer specimens from distant climatic zones, the Duchess decided that she could supplement with figural representations in natural colours the lack of a herbarium. She placed

${ }^{1}$ J. Rostafiński, Księżna wojewodzina Bracławska jako przyrodniczka, p. 294. See also J. Bergerówna, Księżna Pani na Kocku i Siemiatyczach, pp. 81-82.

${ }^{2}$ See A. Jabłonowska, Porzadek robót miesięcznych ... \& R. Bradley, New Improvements of Planting ... .

${ }^{3}$ See A. Jabłonowska, Porzadek robót miesięcznych .... .

${ }^{4}$ See K. Kluk, Dykcjonarz roślinny ... . 
them in closet compartments that contained specimens of the plant kingdom according to Linnaeus' system. The enormous greenhouses in the Duchess's garden partially made up for these shortcomings, and this could be viewed as an addition to the Cabinet. ${ }^{1}$

The specification of Count Sołtyk in the part concerning the plant world was divided into two parts: I. woods and II. fruits from foreign countries, seeds, grains and several plants. In the first part of the specification, out of 46 wood specimens 29 were listed as American by R. Ładowski ${ }^{2}$, while only 4 by Krzysztof $\mathrm{Kluk}^{3}$. In the second part of the specification, out of 83 plant specimens 22 were discribed as American by R. Ładowski and 19 by K. Kluk. Among the plants specified by Sołtyk, K. Kluk confirmed a therapeutic effect for only three: Aquilaria (wood eagles), Guaiac, and Ricinus peruvianum [?], but he described in detail only Guaiac. On the other hand, according to R. Ładowski, 13 of the specified plants had therapeutic importance. The analysis of the publications by Jabłonowska, Kluk, Ladowski and the manuscript of Count Soltyk indicates the likely impact of Jabłonowska's collection and publication to Ładowski's and Kluk's work.

\section{Pharmacopoeia and exotic raw materials}

Since the times of the great geographical discoveries, the suggestions of naturalists about the possibility of using plants from the New World in medicine were not tantamount to their presence in official pharmacopias. The explanation of the reason why so few exotic plants found their way into the official pharmacopias was still the humoral theory that was at the root of the therapy. And so, Guaiacum according to Falloppio, in addition to being hot and dry, had its inner strength that healed the French disease (syphilis). Cesalpino and Faloppio explained this with the simultaneous import of both guaiac and disease from West India. Spanish physician Nicolás Monardes, on the other hand, attributed the characteristics of warm and dry to tobacco and therefore it was used to treat diseases recognized as the result of excess cold and moisture, such as asthma ${ }^{4}$.

One of the most famous physicians at the turn of the $17^{\text {th }}$ and $18^{\text {th }}$ centuries was Herman Boerhaave (1668-1738), called by Albert von Haller communis Europce proceptor (teacher of all Europe), maybe because he achieved a great success in his ability to combine the old humorous concept with the modern mechanistic approach. He also understood very well that the existing commercial interests of the drug market would be jeopardized upon the introduction of new raw materials: all were part of the same medical system, in which such issues as availability, price or medical fashion were as important for the successful commodification of remedies as was their medical efficacy.

\footnotetext{
${ }^{1}$ See Exposé sommaire de l'état actuel du cabinet d'histoire naturelle formé ..., , p. 25.

${ }^{2}$ See R. Ładowski \& Ch.-A.-J. Leclerc de Montlinot, Dykcyonarz stużący do poznania historyi ...

${ }^{3}$ See K. Kluk, Dykcjonarz roślinny ... .

${ }^{4}$ See T. Huguet-Termes, New World Materia Medica .... .

${ }^{5}$ W. Klein, New Drugs for the Dutch Republic, pp. 272-273.
} 
Brokers in the trade of new raw materials and medicinal preparations used such a well-known advertising very effectively, and also conducted mail order sales. The market of antipyretic drugs became big business already in the $18^{\text {th }}$ century and perhaps it was already a prelude to the globalization processes of the $19^{\text {th }}$ century ${ }^{1}$.

The first Polish Pharmacopoeias, however, contained very few of the previously unknown raw materials and they did not have a great impact on the contemporary therapeutic possibilities. In the Polish territories, raw materials from the New World were recorded in Jan Woyna's Pharmacopoeia Cracoviensis of $1683^{2}$, where only five American species among 105 species of plants were identified (Sassafras officinale Nees v. Essenbeck, Guajacum officinale L. and Guajacum sanctum L., Protium heptaphyllum (Aubl) L. March. and Anacardium occidentale L.). By contrast, in the $18^{\text {th }}$-century Jesuit pharmacies, 30 such materials were used already, although they were not pharmacopoeial. Between the $16^{\text {th }}$ and $18^{\text {th }}$ centuries, Jesuit missionaries significantly influenced the worldwide spread of medicines based on exotic medicinal raw materials. One could learn about their healing properties mainly from the works of naturalists, who often used cabinets of natural history as a source of knowledge.

In the first official Polish pharmacopoeia Pharmacopoeia Regni Polonice $(1817)^{3}$, among 311 plant raw materials listed, 114 were of non-European origin, including 16 American ones. In subsequent Polish pharmacopoeias, the number of exotic raw materials decreased.

Today, the number of species on Earth is estimated at 250,000, but only about $5-10 \%$ have so far been tested for pharmacologically active compounds (bioactive molecules that can be used in the process of developing new drugs) ${ }^{4}$. WHO data show that $25 \%$ of modern medicines come from plants that belong to traditional medicine, and natural products and their derivatives account for over $50 \%$ of all drugs used in the world. Numerous literature data indicate the possibility of using biologically active ingredients of plant origin in the prevention and even in the treatment of many diseases, among others diet-related diseases (diabetes, hyperlipidemia, hypertension and other cardiovascular diseases), and even cancer. Valuable bioactive plant ingredients can slow down aging, the development of neurodegenerative diseases, improve well-being and improve quality of life 5 .

The search for modern solutions in modern pharmaceuticals, such as the use of sea sponges as carriers of active substances, indicating the usefulness of byssus $^{6}$ for creating new polymaterials ${ }^{7}$ is reminiscent of reaching for exotic

\footnotetext{
${ }^{1}$ See C. Griffin, Disentangling commodity histories ..., pp. 1-18.

${ }^{2}$ See J. Woyno, Pharmacopea Cracoviensis \& H. Bukowiecki, Farmakopea Krakowska Jana Woyny ... .

${ }^{3}$ See Pharmacopoeia Regni Polonice ... .

${ }^{4}$ See A. D. Kinghorn, Pharmacognosy in the $21^{\text {st }}$ Century.

${ }^{5}$ See E. Cieślik \& A.Gębusia, Charakterystyka właściwości prozdrowotnych ... .

${ }^{6}$ See M. Biniecka (ed.), I Maestri del Bisso, della Seta, del Lino, pp. 1- 43.

${ }^{7}$ See M. J. Harrington, A. Masic, N. Holten-Andersen, J. H. Waite \& P. Fratzl, Iron-clad fibers ... .
} 
specimens from cabinets of natural history. In turn, missionary remedies are still interesting because medicinal plants traditionally used in non-European countries may have great potential for the development of modern phytotherapeutics ${ }^{1}$.

\section{Bibliography}

Anagnostou S., The international transfer of medicinal drugs by the Society of Jesus (sixteenth to eighteenth centuries) and connections with the work of Carolus Clusius, Carolus Clusius in: Towards a cultural history of a Renaissance naturalist, (eds.) F. Egmond, P. Hoftijzer \& R. P. W. Visser, Koninklijke Nederlandse Akademie van Wetenschappen, Amsterdam 2007, pp. 293-312.

Anagnostou S., Mission, pharmacy and international drug transfer in colonial times in: E. Moreno Toral \& A. Ramos Carillo (eds.), Actas del 38. Congreso Internacional de Historia de la Farmacia. Sevilla, 19-22 Septiembre 2007, Sevilla 2009 [CD-Rom].

Arabas I., Przyrodnicy, kolekcjonerzy i teoretycy muzealnictwa in: Kwartalnik Historii Nauki i Techniki, 54, 1/2009, pp.115-130.

Arabas I., A case study of the role of $18^{\text {th }}$-century natural history cabinets, as vehicles of nowledge transfer to the society in: Ch. Friedrich, W.-D. Müller-Jahncke \& S. Anagnostou (eds.), Grenzüberschreitungen in der Pharmazie. Die Vorträge der Pharmaziehistorischen Biennale in Meißen vom 22. bis 24. April 2016 mit einem Anhang: Pharmaziehistorische Reminiszenzen von Dr. Klaus Meyer, Wissenschaftliche Verlagsgesellschaft, Stuttgart 2017, pp. 33-54.

Bauhin K., Pinax theatri botanici, Sumptibus \& typis Ludovici Regis, Basileae Helvet. 1623.

Bergerówna J., Księżna Pani na Kocku i Siemiatyczach, Nakładem Towarzystwa Naukowego z Zasiłkiem Funduszu Kultury Narodowej, Lwów 1936.

Bieńkowski T., Polscy przedstawiciele „scientia curiosa” in: Rozprawy z Dziejów Oświaty 30, 1987, pp. 5-34.

Biniecka M. (ed.), I Maestri del Bisso, della Seta, del Lino, Università Sapienza, Roma 2017.

Bleichmar D., Books, Bodies, and Fields: Sixteenth-Century Transatlantic Encounters with New World Materia Medica in: L. Schiebinger \& C. Swan (eds.), Colonial Botany: Science, Commerce, and Politics, University of Pennsylvania Press, Philadelphia 2005, pp. 83-99.

Bleichmar D. \& Mancall P., Collecting across Cultures: Material Exchanges in the Early Modern Atlantic World, University of Pennsylvania Press, Philadelphia 2011.

Bradley R., New Improvements of Planting and Gardening both Philosophical and Practical, Printed for A. Bettesworth and C. Hitch, London 1739.

${ }^{1}$ See S. Anagnostou, Mission, pharmacy and international drug transfer in colonial times. 
Bukowiecki H., Farmakopea Krakowska Jana Woyny z roku 1683 [Pharmacopea Cracoviensis by Jan Woyno 1683] in: Acta Societatis Botanicorum Poloniae 17, 2017, pp. 13-20.

Brzęk G., Krzysztof Kluk, Wydawnictwo Lubelskie, Lublin 1977.

Cermenati M., Ulisse Aldrovandi e l'America, con frammenti inediti e note esplicative, Tipografia Enrico Voghera, Roma 1906.

Chesneau R. P. Ch., Thèse: Le Père Yvès Paris et son temps (1590-1678) in: Annales de Bretagne et des pays de l'Ouest 54, 1/1947, pp. 179-190.

Cieślik E. \& Gębusia A., Charakterystyka właściwości prozdrowotnych owoców roślin egzotycznych in: Postęy Fitoterapii 2/2012, pp. 93-100.

Czerzeniewska J., Zbieractwo jako krytyka kultury. Przypadek Rousseau in: Przeglad Filozoficzny - Nowa Seria 21, 4/2012, pp. 241-257.

Daston L. \& Park K., Wonders and the Order of Nature (1150-1750), Zone Books, New York 1998.

Daszkiewicz P. \& Bauer A., Specimens from the second collection of Albertus Seba in Poland: the natural history cabinet of Anna Jablonowska (17281800) in: Bibliotheca Herpetologica 6, 2/2006, pp. 16-20.

Daszkiewicz P., Polacy odwiedzajacy gabinet historii naturalnej Jeana Hermanna (1738-1800) w Strasburgu in: Echa Przeszłości 13, 2012, pp. 133142.

Dezallier d'Argenville A. J., La Conchyliologie, ou histoire naturelle des coquilles de mer, d'eau douce, terrestres et fossils; avec un Traité de la Zoomorphose; ou, représentation des Animaux qui les habitent: Ouvrage dans lequel on trouve une nouvelle Méthode de les diviser, vol. 1-3, Guillaume de Bure fils aîné, Paris 1780.

Elbanowski A., Nowy Świat w polskich dykcjonarzach od XVI do początku XIX wieku in: Lingwistyka Stosowana 7, 2013, pp. 7-32.

Elbanowski A., Obraz Nowego Świata w staropolskiej literaturze botanicznej $i$ przyrodniczo-lekarskiej in: Acta Botanica Silesiaca 10, 2014, pp. 207-234.

Encyclopédie, ou dictionnaire raisonné des sciences, des arts et des métiers par une société de gens de lettres mis en ordre et publié par $m$. Diderot et $m$. D'Alembert, vol. 1-28, André François Le Breton, Michel-Antoine David, Laurent Durand \& Antoine-Claude Briasson, Paris 1751-1772.

Exposé sommaire de l'état actuel du cabinet d'histoire naturelle formé à Siemiatycze en Podlasie par J. A. la feue Princesse Donairière Jabłonowska Palatine de Bractaw. Née P. Sapieha. D'après le relevé qui en été fait en mois Août 1801, manuscript, St. Petersburg Branch of the Archives of the Russian Academy of Sciences, P. IV. Op. 1. D 148. c. 13.

Findlen P., Possessing Nature: Museums, Collecting and Scientific Culture in Early Modern Italy, University of California Press, Berkeley 1994.

Ganger S., World Trade in Medicinal Plants from Spanish America, 1717-1815 in: Medical History 59, 1/2015, pp. 44-62.

Griffin C., Disentangling commodity histories: pauame and sassafras in the early modern global world in: Journal of Global History 15, 2020, pp. 118. 
Harrington M. J., Masic A., Holten-Andersen N., Waite J. H. \& Fratzl P., Ironclad fibers: a metal-based biological strategy for hard flexible coatings in: Science, March $4^{\text {th }}, 2010$, pp. 216-220.

Huguet-Termes T., New World Materia Medica in Spanish Renaissance Medicine in: Medical History 45, 2001, pp. 359-376.

Impey O. \& MacGregor A. (eds.), The Origins of Museums: The Cabinet of Curiosities in the Sixteenth-and Seventeenth-Century Europe, Clarendon Press, Oxford 1985.

Jabłonowska A., Porządek robót miesięcznych ogrodnika na cały rok wypisany y na miesiace podzielony, w drukarni pokojowey Siemiatyckiey, Warszawa 1787.

Jagodzińska K., Czas muzeów w Europie Środkowej. Muzea i centra sztuki wspótczesnej (1989-2014), Międzynarodowe Centrum Kultury, Kraków 2014, pp. 26-39.

Kinghorn A. D., Pharmacognosy in the $21^{\text {st }}$ Century in: Journal of Pharmacy and Pharmacology 53, 2001, pp.135-148.

Klein W., New Drugs for the Dutch Republic. The Commodification of Fever Remedies in the Netherlands (c. 1650-1800), The Freudenthal Institute, Utrecht University, Utrecht 2018 [PhD thesis].

Kluk K., Zwierzat domowych i dzikich osobliwie krajowych historii naturalney poczatki $i$ gospodarstwo, vol. 1-4, XX. Scholarum Piarum, Warszawa $1779-1780$.

Kluk K., Dykcjonarz roślinny, w którym podtug układu Linneusza sa opisane rośliny nie tylko krajowe, dzikie, pożyteczne albo szkodliwe: na roli, w ogrodach, oranżeriach utrzymywane: ale oraz i cudzoziemskie, które by w kraju pożyteczne być mogły albo z których mamy lekarstwa, korzenie, farby etc., albo które jakowa nadzwyczajność w sobie mają: ich zdatności lekarskie, ekonomiczne, dla ludzi, koni, bydła, owiec, pszczól etc. utrzymywanie, $z$ poprzedzajacym wykładem słów botanicznych i kilkorakim na końcu regestrem, vol. 1-3, XX. Scholarum Piarum, Warszawa 1786-1788.

Kołodziejczyk J., X. Ładowski i jego Historia Naturalna, przez alfabet ułożona in: Ziemia. Dwutygodnik Krajoznawczy Ilustrowany 12, 1927, pp. 370372.

Koning J. De, Uffelen Van G., Zemanek A. \& Zemanek B., Drawn after nature: the complete botanical watercolours of the $16^{\text {th }}$-century Libri picturati, KNNV Publishing, Zeist 2008.

Lebek K., Osobliwości natury a metoda: filozofia naturalna wobec wyjątku siedemnastowiecznej Anglii in: ER(R)GO. Teoria-Literatura-Kultura 1/2014, pp. 49-60.

Lorentz S., Filozofia muzeów in: Przeszłość przyszłości ... Księga pamiatkowa ku czci Profesora Stanisława Lorentza w setna rocznice urodzin, Warszawa 1999, pp. 9-23.

Ładowski R., Historia naturalna Królestwa Polskiego, czyli zbiór krótki przez alfabet ułożony zwierząt, roślin i minerałów, znajdujących się w Polszcze, Litwie i prowincjach odpadlych. Zebrana z pisarzów godnych wiary, rękopisów $i$ świadków oczywistych, W drukarni uprzywilejowaney Ignacego Grebla, Kraków 1783. 
Ładowski R. \& Leclerc de Montlinot Ch.-A.-J., Dykcyonarz stużacy do poznania historyi naturalney y różnych osobliwszych starożytności, które ciekawi w gabinetach znayduja. Dzieło wielce uzyteczne y ciekawe z francuskiego przełożone przez X. Eadowskiego Piara, vol. 1-2, W drukarni Ignacego Grebla, Kraków 1783.

Marcin z Urzędowa, Herbarz Polski, w Drukarni Łazarzowey, Kraków 1595.

Matthioli P. A., Commentarii, in libros sex Pedacii Dioscoridis Anazarbei, de medica materia, ex Officina Valgrisiana, Venetiis 1554.

Oszajca P. \& Bela Z., Ulisses Aldrovandi, jego kolekcja przyrodnicza oraz zwiazki z polskimi uczonymi in: Opuscula Musealia 21, 2013, pp. 169-179.

Pharmacopoeia Regni Polonice auctoritate Ministerii Administrationis Rerum Internarum et Disciplince Publicae edita a Consilio Supremo Sanitatis, Typographia Juxta Novolipium Nro 646, Warszawa 1817.

Pomian K., Zbieracze i osobliwości. Paryż - Wenecja: XVI-XVIII wiek, transl. A. Pieńkos, PIW, Warszawa 1996.

Raven Ch. E., John Ray, Naturalist: His Life and Works, Cambridge University Press, Cambridge 1942.

Risse G. B., Transcending cultural barriers: The European reception of medicinal plants from the America in: Botanical Drugs of the Americas in the Old and New Worlds, (ed.) W. H. Hein, Wissenschaftliche Verlagsgesellschafte, Stuttgart 1984, pp. 31-42.

Rostafiński J., Księżna wojewodzina Bracławska jako przyrodniczka in: Księga pamiatkowa ku czci Bolestawa Orzechowicza, vol. 2, Tow. dla Popierania Nauki Polskiej, Lwów 1916, pp. 280-303.

Rousseau J. J., The Reveries of the Solitary Walker. Translated, with preface, notes and an interpretative essay by Charles E. Butterworth, New York University Press, New York 1979.

Sadurska-Duffy E., Botanika jako źródło naukowej i osobistej refleksji in: Przeglad Filozoficzny - Nowa Seria 21, 4/2012, pp. 260-271.

Simili E. R., Il teatro della natura di Ulisse Aldrovandi, Compositori, Bologna 2001.

Skrzypek M., Filozofia Diderota, Wydawnictwo IFiS PAN, Warszawa 1996, pp. $22-52$.

Swan C., Collecting Naturalia in the Shadow of Early Modern Dutch Trade in: L. Schiebinger \& C. Swan (eds.), Colonial Botany: Science, Commerce, and Politics, University of Pennsylvania Press, Philadelphia 2005, pp. 223236.

Theophrastus, De historia et causis plantarum, Bartholomaeus Confalonerius, Treviso 1483.

Topol O., Deliss. Płaszczyzny percepcji in: Muzeum sztuki. Antologia, (ed.) M. Popczyk, Universitas, Kraków 2005, pp. 401-410.

Ubrizsy-Savoia A., The influence of new species on the botany of the $16^{\text {th }}$ century in: Asclepio 48, 2/1996, pp. 163-172.

Waźbiński Z., Ut Ars Natura, Ut Natura Ars, Studium z problematyki medycejskiego kolekcjonerstwa drugiej połowy XVI wieku, Wyd. UMK, Torun 2000. 
Woyno J., Pharmacopea Cracoviensis, Impensis Johannis Justi Erythropyli, typis Joh. Andreae, Francofurti 1683.

Wójcik Z., Aleksander Sapieha i warszawskie środowiska przyrodnicze końca XVIII i poczatku XIX w., Wydawnictwa Geologiczne, Warszawa 1970.

Wójcik Z., Ksiadz Jan Krzysztof-pisarz i uczony, Muzeum Rolnictwa im. ks. K. Kluka, Ciechanowiec 2012.

Yves de Paris, La théologie naturelle, vol. 2: De l'immortalité de l'âme, des anges et des démons, N. Buon, Paris 1642.

Zemanek A., Botanika Renesansu w świetle wspótczesnej nauki in: Wiadomości Botaniczne 41, 1/1997, pp. 7-19.

Zemanek A., Renaissance botany and modern science in: Z. Mirek \& A. Zemanek (eds.), Studies in Renaissance botany. Polish Botanical Studies, Guidebook Series 20, Polish Academy of Sciences, W. Szafer Institute of Botany, Kraków 1998, pp. 9-47.

Zemanek A., Ubrizsy-Savoia A. \& Zemanek B., The beginnings of ecological thought in the Renaissance: an account based on the Libri picturati A. 18 30 collection of water-colours in: Archives of Natural History 34, 1/2007, pp. $87-108$. 